\title{
Meta Analysis of the Effect of School-Based Sexual Education on the Risk of Pregnancy and Human Immunodeficiency Virus Infection in Adolescents
}

\author{
Jatu Kartika Akmala'), Eti Poncorini Pamungkasari²), Hanung Prasetya3) \\ ${ }^{1)}$ Masters Program in Public Health, Universitas Sebelas Maret \\ 2)Department of Public Health, Faculty of Medicine, Universitas Sebelas Maret \\ ${ }^{3}$ Health Polytechnics, Ministry of Health Surakarta
}

\section{ABSTRACT}

Background: Adolescent behavior is currently worrying, many adolescents have risky sexual behavior that can lead to pregnancy and HIV. School-based sexual education is given to adolescents to provide knowledge, understanding and prevention of sexual and reproductive health, including pregnancy and HIV among adolescents. The purpose of this study was to estimate the effect of school-based sexual education on the risk of pregnancy and HIV in adolescents based on the results of previous studies.

Subjects and Method: This study is a systematic and meta-analysis study. Article is analyzed by using a randomized controlled trial study design. Several databases were used, including PubMed, Science Direct, BMJ and Google Scholar. The keywords for the article search were "school-based sexual education" OR "school-based sex education" AND "human immunodeficiency virus" AND "unwanted pregnancy" OR "unintended pregnancy" AND adolescent AND "randomized controlled trial". This study is a full-text article with a randomized-controlled trial design. Articles were collected using PRISMA Flow diagrams. Articles that met the inclusion criteria were analyzed using the Review Manager 5.3 application.

Results: There were 12 articles that fulfilled the criteria for a meta-analysis with 9 studies which showed the effect of school-based sexual education on increasing pregnancy prevention behavior by 1.04 times higher compared to non-school based sexual education $(\mathrm{RR}=1.04$; $95 \% \mathrm{CI}=0.95$ to $1.13 ; \mathrm{p}=0.42)$ and 7 studies showed the effect of school-based sexual education on increasing HIV prevention behavior by 1.02 times higher compared to nonschool based sexual education $(\mathrm{RR}=1.02 ; 95 \%$ $\mathrm{CI}=0.94$ to $11 ; \mathrm{p}=0.60$ ).

Conclusion: School-based sexual education affected the behavior of preventing pregnancy and HIV among adolescents.

Keywords: School-based sexual education, pregnancy, HIV, adolescents.

\section{Correspondence:}

Jatu Kartika Akmala. Masters Program in Public Health, Universitas Sebelas Maret. Jl. Ir. Sutami 36A, Surakarta 57126, Central Java. Email: jatu.kartika@student.uns.ac.id.

Cite this as:

Akmala JK, Pamungkasari EP, Prasetya H (2021). The Associations of Clean and Healthy Behavior, Social Capital, and Nutritional Status in Children Under Five in Waingapu Health Center. J Health Promote Behav. o6(01): 67-79. https://doi.org/10.26911/thejhpb.2021.06.01.07.

(c) (†) (-) Journal of Health Promotion and Behavioris licensed under a Creative Commons Journal of Health Promotion and Behavioris licensed under a Creation
Attribution-NonCommercial-ShareAlike 4.0 International License.

\section{BACKGROUND}

Adolescents are the key to sustainable development from the age of 10-19 years old and are the largest generation in history with a population of 1.2 billion people
(WHO, 2021). Adolescent behavior is currently worrying, such as sexual behavior that can lead to violations of norms, ethics in society (Winarni et al. al., 2016). The risks faced by adolescents are related to the 
development of their sexual and reproducetive health, among others: unwanted pregnancy and HIV/AIDS infection (Triwahyudianingsih et al., 2012).

Globally, there are 2.2 million adolescents in the world who are infected with HIV (UNAIDS, 2020). Students in 14 secondary schools in the province of KwaZulu-Natal, South Africa have an HIV prevalence of $6.4 \%$ (Karim et al., 2014). In Indonesia, the number of AIDS sufferers from January to March 2017 was 673 people and 10,376 people were infected with HIV (Nindyastuti et al., 2018). HIV is a top-ranked infectious disease that causes death with high mortality and morbidity rates, and requires diagnosis and long-term therapy(Adita et al., 2017).

Another problem arises with unsafe adolescent sexual behavior is unwanted or planned pregnancies. This can lead to an increasing number of adolescents with premarital pregnancy. Premarital pregnancies tend to be unplanned, and unplanned pregnancies pose a risk of maternal and child morbidity and mortality (Martiniuk, 2003). Pregnancy occurs in 12 million female adolescent aged 15-19 years old and 777,000 girls under the age of 15 give birth each year (WHO, 2020). In the United States, there are $13 \%$ of pregnancies between the ages of 13-19 years old, and $80 \%$ of these pregnancies are unwanted (Leftwich et al., 2017). In Indonesia, the birth rate for adolescents aged 15-19 years old in 2020 is 47.37 per 1000 women (WHO, 2020). Complications during pregnancy and childbirth are the leading cause of death for girls aged 15-19 years old worldwide(UNFPA, 2018).

The health consequences are high for adolescent mothers and their babies, the risks are eclampsia, prematurity, low birth weight, increased mortality, intrapartum death, and miscarriage (Leftwich et al.,
2017). Early sexual behavior can occur due to lack of knowledge of adolescents about sexual education or sexual and reproductive health education. Many adolescents who become pregnant are pressured or forced to drop out of school. These findings signal the need for effective sexual education for adolescents(Shanklin et al., 2007).

Several interventions have been carried out, one of them is to reduce the vulnerability of adolescents to STDs, including HIV, such as: preventive education in schools; services provided at youth centres, including condom distribution; youth-friendly health centers that encourage the use of prevention services; school-based health services; conditional cash transfers to encourage youth to stay in school or to avoid risky sexual behavior; various community-based interventions; and unconditional cash transfers (Mavedzenge et al., 2014). Knowledge is one component in the formation of someone's attitude. With insufficient knowledge, adolescents will tend to have negative attitudes about their sexuality (Triwahyuningsih et al., 2012)

Based on the high incidence of pregnancy and HIV, as well as the need for proper handling of these, the researchers were interested in studying the effect of school-based sexual education on the risk of pregnancy and HIV among adolescents. The data obtained would be analyzed using a systematic review and meta-analysis by synthesizing the results of primary studies involving school-based interventions on the risk of pregnancy and HIV in adolescents.

\section{SUBJECTS AND METHOD}

\section{Study Design}

The study design used in this study was a systematic review and meta-analysis, using the PRISMA diagram flow guidelines. Article searches were conducted by using jour- 
nal databases, including PubMed, Research Gate, Science Direct, BMJ and Google Scholar. The keywords used are"schoolbased sexual education" OR "school-based sex education" AND "human immunodeficiency virus" AND "unwanted pregnancy" OR "unintended pregnancy" AND adolescent AND "randomized controlled trial".

\section{Inclusion Criteria}

In this study, the inclusion criteria were articles using a randomized controlled trial study design, articles were in English, the analysis used was bivariate with Relative Risk (RR), the study subjects were male and female adolescents, the intervention was school-based sexual education and the outcome was the risk of pregnancy and HIV.

\section{Exclusion Criteria}

The exclusion criteria in this study were articles published in full text before 2000 and in languages other than English.

\section{Operational Definition}

In formulating study problems, the researchers used PICO. The populations were male and female adolescents. Intervention was school-based sexual education, with a comparison of not given school-based sexual education.

Sexual education is an effort to provide knowledge to groups of adolescents about sexuality so that they can change their sexual behavior into a more responsible form.

Pregnancy is the outcome after being given a school-based sexual education intervention. Actions taken by adolescents in an effort to prevent pregnancy can be in the form of using condoms or hormonal contraception.
HIV is the outcome after receiving a school-based sexual education intervention. Actions taken by adolescents in an effort to prevent HIV can be in the form of using condoms or hormonal contraception.

\section{Study Instrument}

An assessment of the quality of research articles has been carried out by the CEBM University Of Oxford.

\section{Data Analysis}

The Review Manager application (RevMen 5.3) was used in analyzing the data in this study. The results of data analysis were in the form of effect size values and study heterogeneity which later on the results of the data that have been analyzed and interpreted in the form of forest plots and funnel plots.

\section{RESULTS}

The process of searching for articles was done by searching through a database with journals that can be seen in Figure 1. There were 1057 articles identified from the database, after the removal process of published articles, 709 of them fulfilled the requirements for a full text review. Articles were excluded for several reasons, therefore, 12 articles were included in the synthesis and meta-analysis studies.

Research from primary studies related to the effect of school-based sexual education on the risk of pregnancy and HIV in adolescents consisted of 12 studies from 7 countries on 3 continents, namely 3 studies from the Americas, 4 studies from the African continent, and 2 studies from the European continent. 


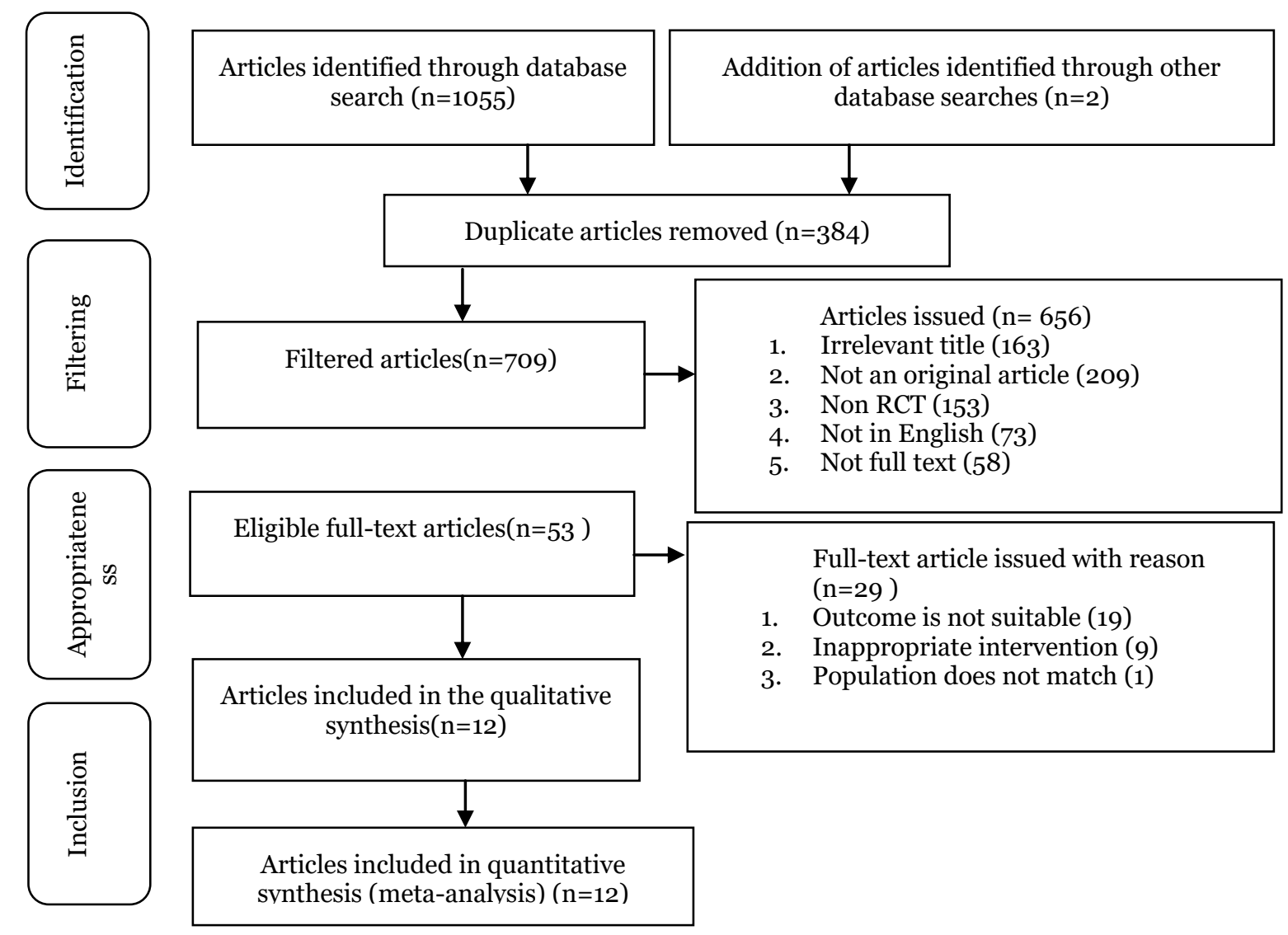

Figure 1. Review Process Flowchart 
Table 1. Assessment of Study Quality

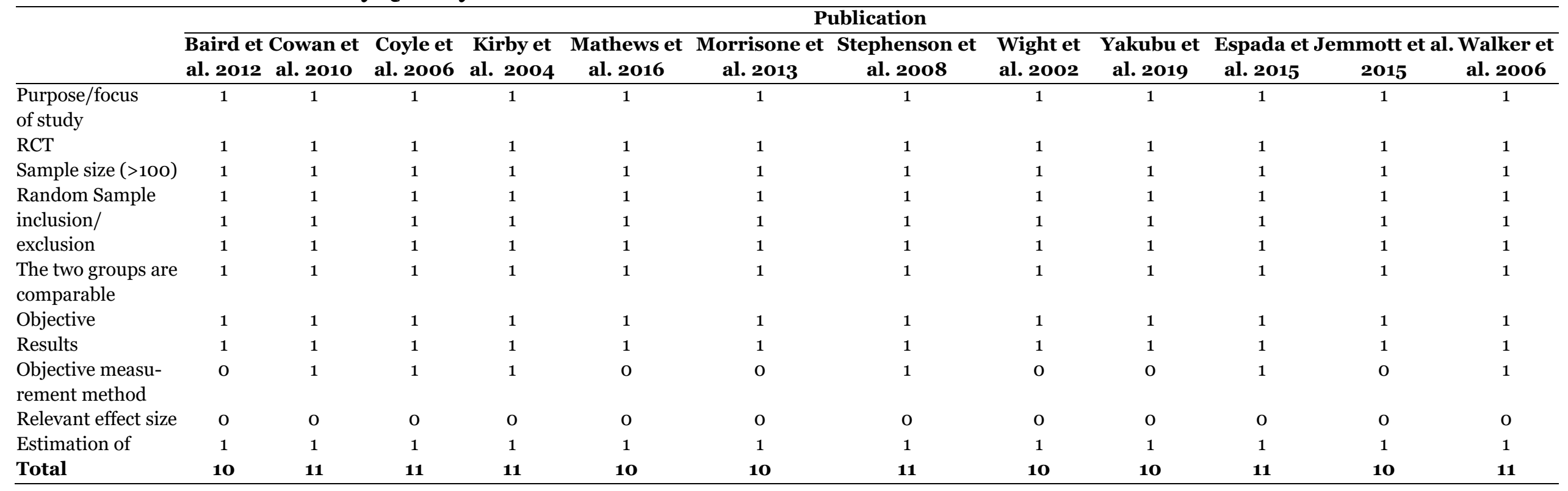

Table 2. Summary Source ofSchool-Based Sexual Education on Pregnancy Prevention Behavior

\begin{tabular}{|c|c|c|c|c|c|c|c|}
\hline Author (Year) & Location & $\begin{array}{l}\text { Study } \\
\text { Design }\end{array}$ & $\begin{array}{l}\text { Sample } \\
\text { Size }\end{array}$ & Population & Intervention & Comparison & Outcome \\
\hline et al., & Malawi & $\mathrm{RCT}$ & 3796 & $\begin{array}{l}\text { School } \\
\text { Adolescents }\end{array}$ & $\begin{array}{l}\text { School Based Sexual } \\
\text { Education }\end{array}$ & $\begin{array}{l}\text { Education for Adolescents } \\
\text { who are Dropout }\end{array}$ & The use of condom \\
\hline $\begin{array}{l}\text { Cowan } \\
(2010)\end{array}$ & Zimbabwe & RCT & 6791 & $\begin{array}{l}\text { School } \\
\text { Adolescents }\end{array}$ & $\begin{array}{l}\text { School Based Sexual } \\
\text { Education }\end{array}$ & $\begin{array}{l}\text { Community Based } \\
\text { Education }\end{array}$ & The use of condom \\
\hline $\begin{array}{l}\text { Coyle } \\
(2006)\end{array}$ & $\begin{array}{l}\text { California, } \\
\text { USA }\end{array}$ & RCT & $\begin{array}{l}527 \\
460\end{array}$ & $\begin{array}{l}\text { School } \\
\text { Adolescents }\end{array}$ & $\begin{array}{l}\text { School Based Sexual } \\
\text { Education }\end{array}$ & $\begin{array}{l}\text { Non School Based Sexual } \\
\text { Education }\end{array}$ & The use of condom \\
\hline $\begin{array}{l}\text { Kirby et al., } \\
(2004)\end{array}$ & Texas, USA & RCT & 2134 & $\begin{array}{l}\text { School } \\
\text { Adolescents }\end{array}$ & $\begin{array}{l}\text { School Based Sexual } \\
\text { Education }\end{array}$ & Adolescents Group & The use of condom \\
\hline $\begin{array}{l}\text { Mathews et al., } \\
\text { (2016) }\end{array}$ & South Africa & $\mathrm{RCT}$ & 3451 & $\begin{array}{l}\text { School } \\
\text { Adolescents }\end{array}$ & $\begin{array}{l}\text { School Based Sexual } \\
\text { Education }\end{array}$ & $\begin{array}{l}\text { Non School Based Sexual } \\
\text { Education }\end{array}$ & The use of condom \\
\hline Morrison-Beedy & USA & $\mathrm{RCT}$ & 738 & School & Theory Based Sexual & Health Promotion & The use of condom \\
\hline
\end{tabular}


et al., (2013)

Stephenson et al.,

(2008)

Wight et al.,

(2002)

Yakubu et al.,

(2019)

\begin{tabular}{|c|c|c|c|}
\hline & & & Adolescents \\
\hline England & RCT & 9508 & School \\
\hline Scotland & RCT & 7616 & $\begin{array}{l}\text { Adolescents } \\
\text { School } \\
\text { Adolescents }\end{array}$ \\
\hline Ghana & RCT & 363 & $\begin{array}{l}\text { School } \\
\text { Adolescents }\end{array}$ \\
\hline
\end{tabular}

Education

School Based Sexual Education with Peer School Based Sexual Education with SHARE Program Comprehensive School Normal class sexual The use of condom Based Sexual Education

Table 3. Summary Source of School-Based Sexual Education on Human Immunodeficiency Virus Prevention Behavior

\begin{tabular}{|c|c|c|c|c|c|c|c|}
\hline Author (Year) & Location & $\begin{array}{l}\text { Study } \\
\text { Design }\end{array}$ & $\begin{array}{l}\text { Sample } \\
\text { Size }\end{array}$ & Population & Intervention & Comparison & Outcome \\
\hline Coyle et al., (2006) & $\begin{array}{l}\text { California, } \\
\text { USA }\end{array}$ & RCT & 527,460 & $\begin{array}{l}\text { School } \\
\text { Adolescents }\end{array}$ & $\begin{array}{l}\text { School Based Sexual } \\
\text { Education }\end{array}$ & $\begin{array}{l}\text { No School-Based Sexual } \\
\text { Education }\end{array}$ & $\begin{array}{l}\text { The use of } \\
\text { condom }\end{array}$ \\
\hline $\begin{array}{l}\text { Espada et al., } \\
\text { (2015) }\end{array}$ & Spanish & $\mathrm{RCT}$ & 1563 & $\begin{array}{l}\text { School } \\
\text { Adolescents }\end{array}$ & $\begin{array}{l}\text { School Based Sexual } \\
\text { Education }\end{array}$ & $\begin{array}{l}\text { No School-Based Sexual } \\
\text { Education }\end{array}$ & $\begin{array}{l}\text { The use of } \\
\text { condom }\end{array}$ \\
\hline $\begin{array}{l}\text { Jemmott et al., } \\
\text { (2015) }\end{array}$ & South Africa & $\mathrm{RCT}$ & 1057 & $\begin{array}{l}\text { School } \\
\text { Adolescents }\end{array}$ & $\begin{array}{l}\text { School Based Sexual } \\
\text { Education with Theory }\end{array}$ & $\begin{array}{l}\text { No School-Based Sexual } \\
\text { Education }\end{array}$ & $\begin{array}{l}\text { The use of } \\
\text { condom }\end{array}$ \\
\hline Mathews et al., & South Africa & RCT & 3451 & $\begin{array}{l}\text { School } \\
\text { Adolescents }\end{array}$ & $\begin{array}{l}\text { School Based Sexual } \\
\text { Education }\end{array}$ & $\begin{array}{l}\text { No School-Based Sexual } \\
\text { Education }\end{array}$ & $\begin{array}{l}\text { The use of } \\
\text { condom }\end{array}$ \\
\hline $\begin{array}{l}\text { Morrison-Beedy et } \\
\text { al., (2013) }\end{array}$ & USA & $\mathrm{RCT}$ & 738 & $\begin{array}{l}\text { School } \\
\text { Adolescents }\end{array}$ & $\begin{array}{l}\text { Theory Based Sexual } \\
\text { Education }\end{array}$ & Health Promotion & $\begin{array}{l}\text { The use of } \\
\text { condom }\end{array}$ \\
\hline $\begin{array}{l}\text { Walker et al., } \\
(2006)\end{array}$ & Mexico & RCT & 10.954 & $\begin{array}{l}\text { School } \\
\text { Adolescents }\end{array}$ & $\begin{array}{l}\text { School Based Sexual } \\
\text { Education with the United } \\
\text { Nations Program Guidelines } \\
\text { on HIV/AIDS }\end{array}$ & $\begin{array}{l}\text { No School-Based Sexual } \\
\text { Education }\end{array}$ & $\begin{array}{l}\text { The use of } \\
\text { condom }\end{array}$ \\
\hline Wight et al., (2002) & Scotland & RCT & 7616 & $\begin{array}{l}\text { School } \\
\text { Adolescents }\end{array}$ & $\begin{array}{l}\text { School Based Sexual } \\
\text { Education with SHARE } \\
\text { Program Comprehensive } \\
\text { School Based Sexual } \\
\text { Education }\end{array}$ & $\begin{array}{l}\text { Normal class sexual } \\
\text { education }\end{array}$ & $\begin{array}{l}\text { The use of } \\
\text { condom }\end{array}$ \\
\hline
\end{tabular}


Akmala et al./ The Effect of School-Based Sexual Education on the Risk of Pregnancy and HIV Infection

\section{The Effect of School-Based Sexual Education on Pregnancy Risk}

The study identified from the review results obtained 9 articles that met the requirements as a source for a meta-analysis of the effect of school-based sexual education on the risk of pregnancy from 3 continents, including the Africa, America and the Europe.

\section{a. Forest Plot}

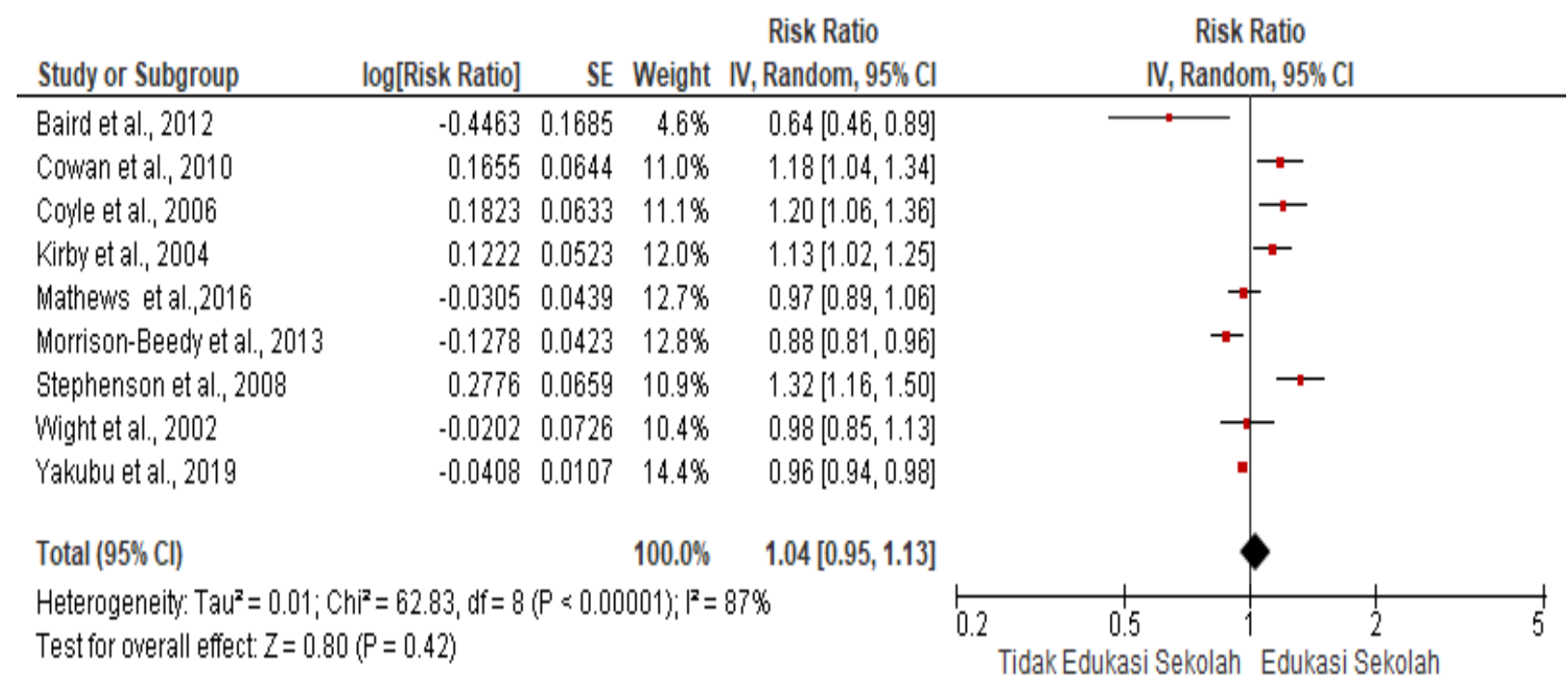

Figure 2. Forest Plot of the Effect of School-Based Sexual Education on Pregnancy Risk

Based on the results of the Forest Plot (Figure 2), it was shown that school-based sexual education has an effect of 1.04 times on the behavior of preventing pregnancy and it was b. Funnel Plot

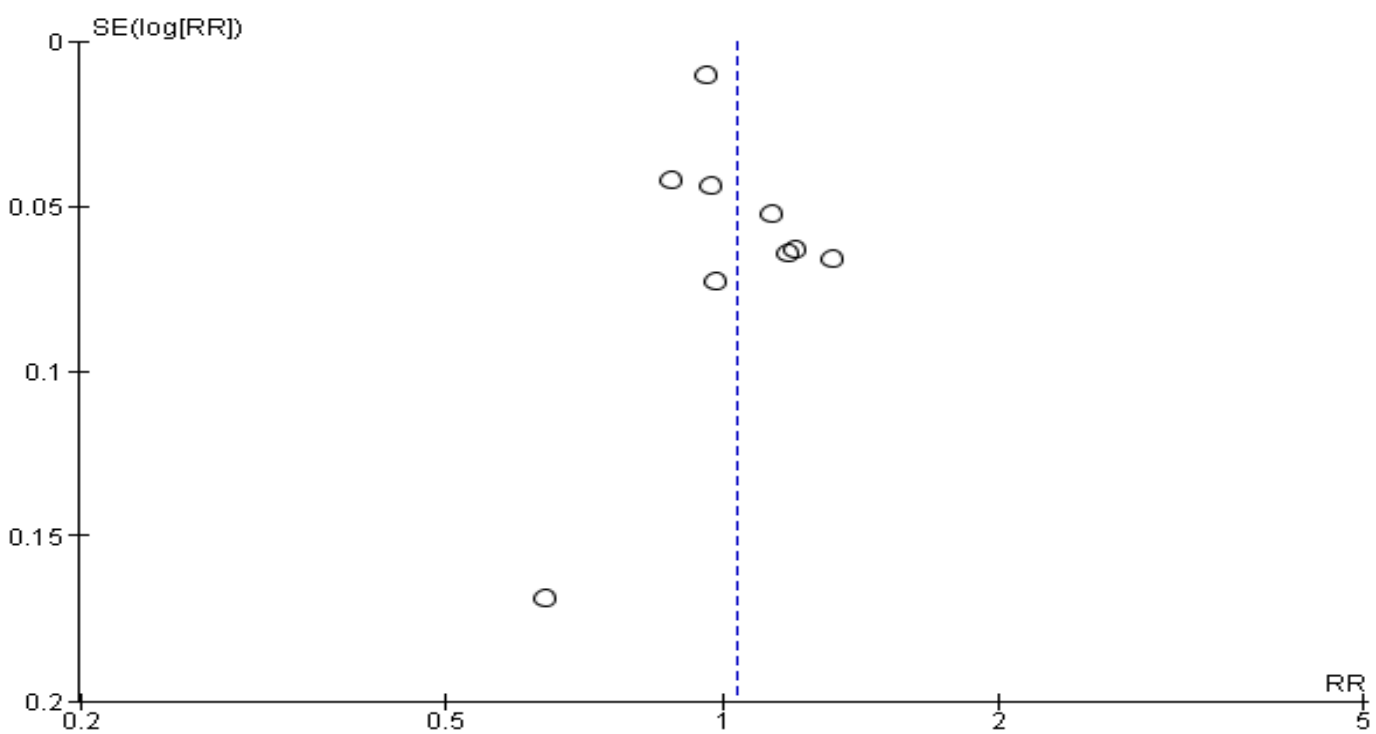

Figure 3. Funnel plot of the effect of school-based sexual education on pregnancy risk 
Akmala et al./ The Effect of School-Based Sexual Education on the Risk of Pregnancy and HIV Infection

The funnel plot (Figure 3) showed no publication bias with: symmetrical plots on the right and plots on the left where 5 plots are on the left and 4 plots are on the right.

2. The effect of school-based sexual education on the risk of HIV

The study identified from the review results obtained 7 articles that met the requirements as a source for a meta-analysis of the effect of school-based sexual education on human immunodeficiency virus originating from 3 continents, including the African, the American and the European continent.

\section{a. Forest Plot}

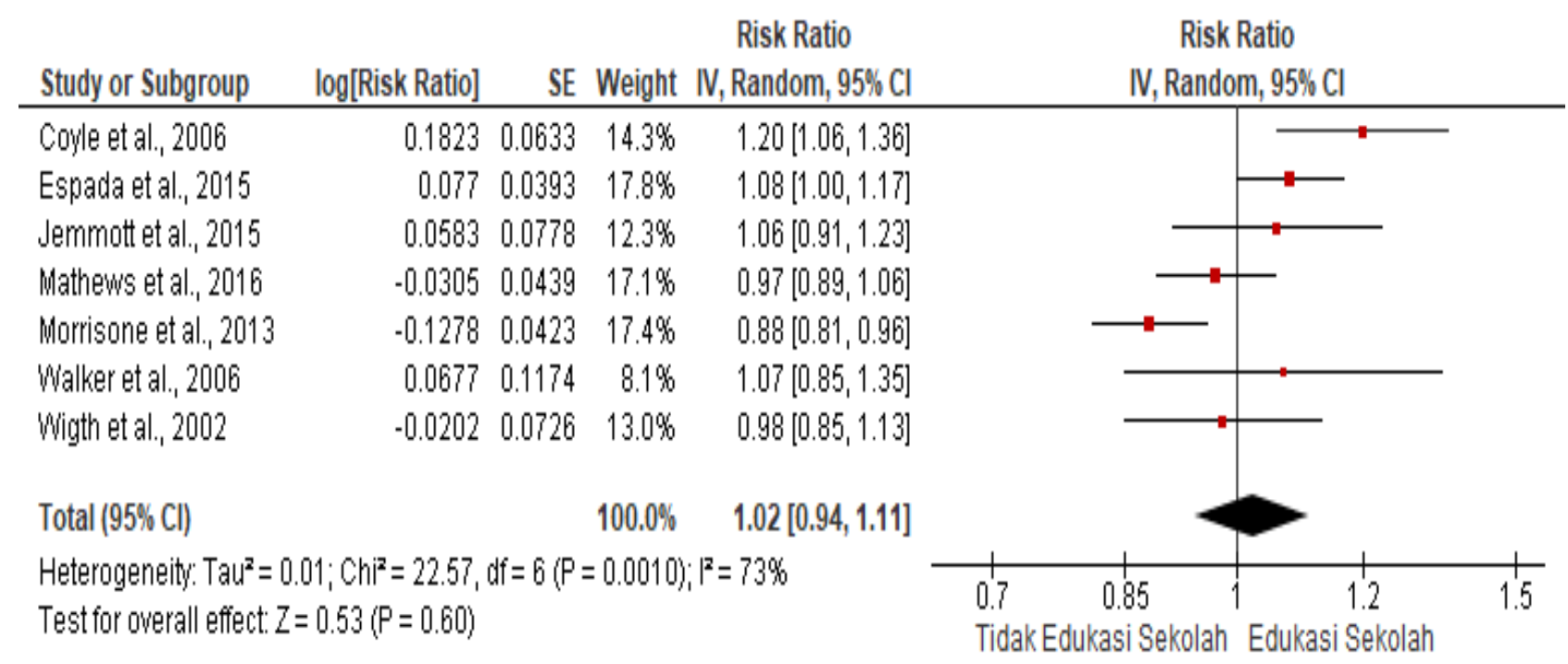

Figure 4. Forest Plot of the Effect of School-Based Sexual Education on HIV Risk

Based on the results of the Forest Plot (Figure 4), it showed that the effect of school-based sexual education was 1.02 times on HIV prevention behavior and was b. Funnel Plot

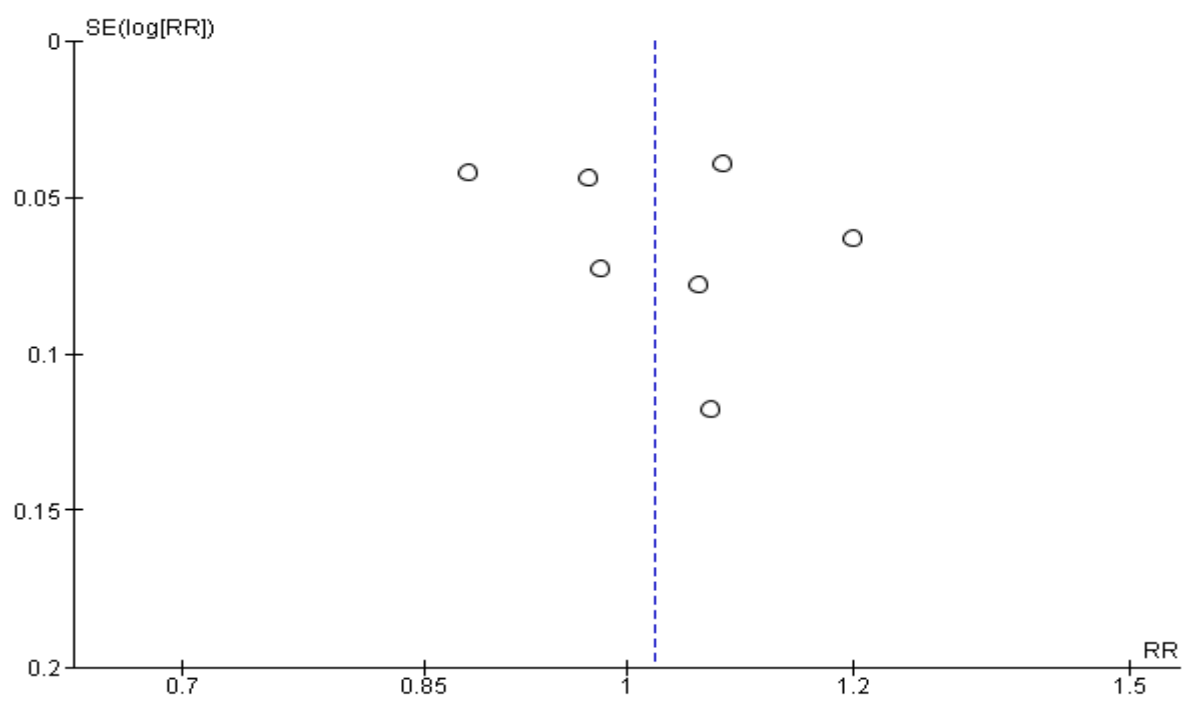

Figure 5. Funnel Plot of the Effect of School-Based Sexual Education on HIV Risk not statistically significant $(\mathrm{p}=0.60)$. The heterogeneity of the research data showed $\mathrm{I}^{2}=73 \%$ so that the distribution of the data was heterogeneous(random effect model). 
The funnel plot (Figure 5) showed no publication bias with: symmetrical plots on the right and plots on the left where 4 plots are on the right and 3 plots are on the left.

\section{DISCUSSION}

This systematic and meta-analysis study raised the theme of the effect of schoolbased sexual education on the risk of pregnancy and HIV. This study discussed data on behavior to prevent pregnancy and HIV in adolescents which were considered important because of the high rate of pregnancy and HIV among adolescents.

\section{The effect of sexual education on pregnancy risk}

The results of a meta-analysis of 9 articles on the effect of school-based sexual education on the risk of pregnancy are summarized in the forest plot. The forest plot in Figure 4.2 showed that school-based sexual education is 1.04 times more likely in increasing pregnancy prevention behavior in adolescents. This result was not statistically significant $(\mathrm{RR}=1.04 ; 95 \% \mathrm{CI}=0.95$ to 1.13; $\mathrm{p}=0.42$ ).

According to Mason-Jones et al. (2012), the school environment plays an important role in the socialization of adolescent development and as an appropriate place for interventions to promote adolescent sexual and reproductive health. Stephenson et al. (2008) stated that good health education can delay the desire for sexual activity and pregnancy prevention behavior. In line with Kirby et al. (2009), who stated that schools have become venues for many sexual and reproductive health programs which are considered to have successfully adapted from theories and aim to change attitudes, intentions, behaviors, and social norms through increasing knowledge and understanding about the risks of early sexual initiation, and the importance of contraceptive use. and/or condoms. The CDC (2015) emphasizes that when condoms are used correctly and consistently, they can provide protecttion against pregnancy and disease. Consistent condom use is also important to reduce unplanned pregnancies, $35-40 \%$ of South African women have their first child at the age of 19, and most of them are unplanned pregnancies (Jewkeset al., 2010 ).

Taylor et al. (2014) revealed that the average value of pregnancy prevention behavior with the use of condoms signifycantly increased, but this did not have an impact on the consistency of condom use among adolescents for pregnancy prevention behavior. This inconsistent condom use among adolescents is consistent with the findings in the authors' meta-analysis which stated that there is no strong evidence for the effect of school-based sexual education on pregnancy prevention behavior in adolescents.

There was a statistically insignificant effect on the results of the meta-analysis conducted by the researchers in 9 primary studies. This indicates that there is less strong evidence of the effectiveness of school-based sexual education as an effort to prevent pregnancy in adolescents. Markham et al. (2012) revealed that conducting comprehensive sexual education can encourage delaying sexual intercourse, and provide information on pregnancy and disease prevention behaviors.

\section{The Effect of Sexual Education on HIV Risk}

The results of a meta-analysis of 7 articles on the effect of school-based sexual education on HIV risk were summarized in the forest plot. The forest plot in Figure 4.4 showed that school-based sexual education is $\mathbf{1 . 0 2}$ times more likely at increasing HIV prevention behavior in adolescents. This result was not statistically significant $(R R=$ 
Akmala et al./ The Effect of School-Based Sexual Education on the Risk of Pregnancy and HIV Infection

1.02; $95 \% \mathrm{CI}=0.94$ to $1.11 ; \mathrm{p}=0.60)$.

Schalett et al. (2011) emphasized on public health which showed that the pedagogical approach was effective in reducing the rates of pregnancy, STDs and HIV infection. In line with the findings of Kirby et al. (2006) which stated that comprehensive sexual education has better results in increasing the use of condoms in reducing sexual risk.

Mathews et al. (2016) stated that education provided to adolescents does not lead to a reduction in sexual behavior related to HIV prevention. School-based sexual education in adolescents can lead to improvements in knowledge and increased self-efficacy, however, it does not signifycantly affect infection risk behavior and high sexual risk (Shepherd et al., 2010). School adolescents in the intervention also had increased knowledge about HIV. The intervention did not significantly increase condom use, and the reason is not clear, although these results are similar to other South African school-based studies (Horrison et al., 2016). Until this day, none of the greater school-based sexual education in adolescent HIV prevention in Africa has reduced the risk of developing HIV (Cowan et al., 2010). This is in line with this study, which showed that there is no strong evidence for the effect of school-based sexual education on HIV prevention behavior among adolescents.

There was a statistically insignificant effect on the results of the meta-analysis conducted by researchers in 7 primary studies. This indicated that there was less strong evidence of the effectiveness of school-based sexual education as an effort to prevent HIV behavior in adolescents. According to Mason-Jones et al. (2012), curriculum-based education encourages improved sexual and reproductive health outcomes for adolescents. In line with
Jemmot et al. (2015) which stated that theory-based sexual education with adolescents has a long-term effect in preventing HIV behavior.

\section{AUTHOR CONTRIBUTION}

Jatu Kartika Akmala is the main researcher who selected the topic, searched for and collected study data. Eti Poncorini Pamungkasari and Hanung Prasetya played a role in analyzing data and reviewing research documents.

\section{FUNDING AND SPONSORSHIP}

This study is self-funded.

CONFLICT OF INTEREST

There is no conflict of interest.

\section{ACKNOWLEDGMENT}

The researchers would like to thank to the provider of database, PubMed, Research Gate, Science Direct, BMJ and Google Scholar.

\section{REFERENCES}

Adita K, Demartoto A, Pamungkasari EP (2017). Path analysis on the factors affecting people's behavior in HIV/ AIDS countermeasure on people living with HIV/AIDS (PLWHA) in Solo Plus Peer Support Group, Surakarta. J Health Promote Behav. 2(1): 41-54. https://doi.org/10.26911/thejhpb.2017.02.01.04.

Baird SJ, Garfein S, McIntosh CT, Ozler B (2012). EGect of a cash transfer programme for schooling on prevalence of HIV and Herpes Simplex Type 2 in Malawi: A cluster randomised trial. Lancet. 379(9823):1320-9.

Brahmbhatt $\mathrm{H}$, Kågesten $\mathrm{A}$, Emerson $\mathrm{M}$, Decker MR, Olumide AO, Ojengbede O, Lau C, et al. (2014). Prevalence and determinants of adolescent pregnancy 
Akmala et al./ The Effect of School-Based Sexual Education on the Risk of Pregnancy and HIV Infection

in urban disadvantaged settings across five cities. J Adolesc Health. 55(6): S48-S57. doi:10.1016/j.jadohealth.2014.07.023.

Burnett SM, Weaver MR, Mody-Pan PN, Thomas LA, Mar CM (2011). Evaluation of an intervention to increase human immunodeficiency virus testing among youth in Manzini, Swaziland: A randomized control trial. $\mathrm{J}$ Adolesc Health. 48(5): 507-13. doi: 10.1016/j.jadohealth.2010.08.015.

CDC (2015). Sexually Transmitted diseases treatment guidelines. Retrieved from https://www.cdc.gov/std/tg2015/spe cialpops.htm\#adol

CEBM (2014). Checklist for the critical appraisal of a controlled study. 10, 12. Retrieved from http://www.cebma.org/wp-content/uploads/Critical-

Appraisal-Questions-for-a-Survey.pdf

Christian P, Smith ER (2018). Adolescent Undernutrition: Global burden, physiology, and nutritional risks. Ann Nutr Metab. 72(4):316-328. doi: 10.$1159 / 000488865$.

Cowan FM, Pascoe SJ, Langhaug LF, Mavhu W, Chidiya S, Jaffar S, Mbizvo MT, Stephenson JM, et al. (2010). The Regai Dzive Shiri Project: Results of a randomized trial of an HIV prevention intervention for youth. AIDS. 24(16): 2541-52. doi: 10.1097/QAD.obo13e32833e77c9.

Coyle KK, Kirby DB, Robin LE, Banspach SW, Baumler E, Glassman JR (2006). A randomized trial of An HIV, other STDs, and pregnancy prevention intervention for alternative school students. AIDS Educ Prev. 18(3):187203. doi: 10.1521/aeap.2006.18.3.187. PMID: 16774462.

Islam MS, Rahman MM (2008). Sex Education: An Islamic View. The Dhaka University Journal of Islamic
Studies. 2(1). January-June.

James S, Van Rooyen D, StrümpherDcurJ (2012). Experiences of teenage pregnancy among Xhosa families. Midwifery. 28(2): 190-197. doi:10.1016/j.midw.2011.04.003.

Jemmott JB, Jemmott LS, O'Leary A, Ngwane Z, Lewis DA, Bellamy SL, Icard LD, et al. (2015). HIV/STI riskreduction intervention efficacy with South African adolescents over 54 months. Health Psychol. 34(6): 61021. doi: 10.1037/heaoooo140.

Jewkes R, Morrell R, Christofides N (2009). Empowering teenagers to prevent pregnancy: Lessons from South Africa. Cult Health Sex. 11(7): 675-88. doi: 10.1080/13691050902846452.

Khader YS, Batieha A, Al-Fursan RK, AlHader R, Hijazi SS (2017). Rate of Teenage Pregnancy in Jordan and Its Impact on Maternal and Neonatal Outcomes. Int J Pediatr Adolesc Med. 31(6): 1-8. doi: 10.1515/ijamh-20170075 .

Kirby DB (2008). The impact of abstinence and comprehensive sex and STD/HIV education programs on adolescent sexual behavior. Sexuality Research and Social Policy. 5(3): 18-27. doi: 10.1525/srsp.2008.5.3.18.

Kirby DB, Baumler E, Coyle KK, BasenEngquist K, Parcel GS, Harrist R, Banspach SW (2004). The "Safer Choices" intervention: Its impact on the sexual behaviors of different subgroups of high school students. J Adolesc Health. 35(6):442-52. doi: 10.1016/j.jadohealth.2004.02.006.

Mason-Jones AJ, Crisp C, Momberg M, Koech J, De Koker P, Mathews C (2012). A systematic review of the role of school-based healthcare in adolescent sexual, reproductive, and mental health. Syst Rev. 1:49. doi: 
Akmala et al./ The Effect of School-Based Sexual Education on the Risk of Pregnancy and HIV Infection

10.1186/2046-4053-1-49.

Mathews C, Eggers SM, Townsend L, Aarø LE, de Vries PJ, Mason-Jones AJ, De Koker P, et al. (2016). Effects of PREPARE, a multi-component, school-based HIV and intimate partner violence (IPV) prevention programme on adolescent sexual risk behaviour and IPV: Cluster randomised controlled trial. AIDS Behav. 20(9): 1821-40. doi: 10.1007/s10461016-1410-1.

Mavedzenge SN, Luecke E, Ross DA (2014). Effective approaches for programming to reduce adolescent vulnerability to HIV infection, HIV Risk, and HIVrelated morbidity and mortality: A systematic review of systematic reviews. J Acquir Immune Defic Syndr. 66 Suppl2:S154-69. doi: 10.1097/QAI.0000000000000178.

Morales A, Espada JP, Orgilés M, Escribano S, Johnson BT, Lightfoot M (2018). Interventions to reduce risk for sexually transmitted infections in adolescents: A meta-analysis of trials, 2008-2016. PLoS ONE 13(6): e0199421. doi: 10.1371/journal.pone.0199421.

Morrison-Beedy D, Jones SH, Xia Y, Tu X, Crean HF, Carey MP (2013). Reducing sexual risk behavior in adolescent girls: Results from a randomized controlled trial. J Adolesc Health. 52(3): 314-21. doi: 10.1016/j.jadohealth.2012.07.005.

Murti B (2018). Prinsip dan Metode Riset Epidemiologi (5th ed.) (Principles and Methods of Epidemiological Research (5th ed.)). Program Studi Ilmu Kesehatan Masyarakat, Program Pascasarjana, Universitas Sebelas Maret.

Nindiyastuti NAI, Prasetya H, Murti B (2018). Determinants of mobile voluntary counselling and testing of
HIV use among gay in Surakarta, Central Java. J Health Promote Behav. 3(3): 155-165. https://doi.org/10.26911/thejhpb.2018.03.03.03.

Poudel S, Upadhaya N, Khatri RB, Ghimire $P R$ (2018). Trends and factors associated with pregnancies among adolescent women in Nepal: Pooled analysis of Nepal demographic and health surveys (2006, 2011 and 2016). PLoS One. 13(8):e0202107. doi: 10.1371/journal.pone.0202107.

Pratiwi GT, Prasetya H, Murti B (2018). the contextual effect of school on the premarital sex among adolescents in Bantul, Yogyakarta. J Health Promote Behav. 3(4): 240-247.doi: 10.26911/thejhpb.2018.03.04.03.

Safitri DA, Rahardjo SS, Murti B (2020). Effects of peer-based intervention on prevention behavior of sexually transmitted infections and unwanted pregnancy in adolescents: A meta analysis. J Matern Child Health. 05(06): 693704. https://doi.org/10.26911/thejmch.2020.05.06.09.

Setiowati TA, Pamungkasari EP,Prasetya $\mathrm{H}$ (2019). Application of Theory of Planned Behavior on Sexual Behavior in Female Adolescents. $\mathrm{J}$ Health Promote Behav. 4(2): 126-136. doi: 10.26911/thejhpb.2019.04.02.05.

Siddaway AP, Wood AM, Hedges LV (2019). How to do a systematic review: A best practice guide for conducting and reporting narrative reviews, meta-analyses, and meta-syntheses. Annual Review of Psychology. https://doi.org/10.1146/annurev-psych-010418-102803.

Sinclair J, Kahn LG, Rowe DA, Mazzotti VL, Hirano KA, Knowles C (2017). Collaborating to plan and implement a sex education curriculum for individuals with disabilities. Career Development 
Akmala et al./ The Effect of School-Based Sexual Education on the Risk of Pregnancy and HIV Infection

and Transition for Exceptional Individuals. 40(2): 123-128. doi:10.1177/2165143416670136.

Stephenson J, Strange V, Allen E, Copas A, Johnson A, Bonell C, Babiker A, Oakley A et al. (2008). The long-term eGects of a peer-led sex education programme (RIPPLE): A cluster randomised trial in schools in England. PLoS Med. 5(11): e224. doi: 10.1371/journal.pmed.0050224.

Walker D, Gutierrez JP, Torres P, Bertozzi SM (2006). HIV prevention in Mexican schools: Prospective randomised evaluation of intervention. BMJ. 332 (7551): 1189-94. doi: $10.1136 / \mathrm{bmj} \cdot 3^{-}$ 8796.457407.80.

WHO (2020). Adolescent Pregnancy. World Health Organization. Retrieved fromhttps://www.who.int/newsroom/fact-sheets/detail/adolescentpregnancy

WHO (2021). Maternal , Newborn, Child and Adolescent Health and Ageing. World Health Organization. Retrieved fromhttps://www.who.int/data/mate rnal-newborn-child-adolescent-ageing/indicator-explorer-new/mca/adolescent-birth-rate-(per-1-ooofemales-aged-15-19-years).

Wight D, Raab GM, Henderson M, Abraham C, Buston K, Hart G, Scott S (2002). Limits of teacher delivered sex education: Interim behavioural outcomes from randomized trial. BMJ. 324(7351): 1430. doi: 10.1136/bmj.324.7351.1430. 